WellBeing International

WBI Studies Repository

$7-1980$

\title{
Sampling Problems and Interpretation of Chemical Analysis of Mineral Springs Used by Wildlife
}

\author{
D. Fraser \\ Ontario Ministry of Natural Resources \\ E. Reardon \\ University of Waterloo \\ F. Dieken \\ Ontario Ministry of the Environment \\ B. Loescher \\ Ontario Ministry of the Environment
}

Follow this and additional works at: https://www.wellbeingintlstudiesrepository.org/habaman

Part of the Animal Studies Commons, Environmental Studies Commons, and the Terrestrial and Aquatic Ecology Commons

\section{Recommended Citation}

Fraser, D., Reardon, E., Dieken, F., \& Loescher, B. (1980). Sampling problems and interpretation of chemical analysis of mineral springs used by wildlife. The Journal of Wildlife Management, 623-631.

This material is brought to you for free and open access by WellBeing International. It has been accepted for inclusion by an authorized administrator of the WBI Studies Repository. For more information, please contact wbisr-info@wellbeingintl.org.

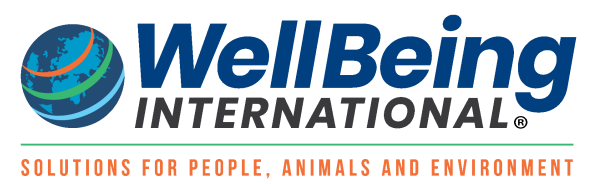




\title{
Sampling Problems and Interpretation of Chemical Analysis of Mineral Springs Used by Wildlife
}

\author{
D. Fraser ${ }^{1}$, E. Reardon ${ }^{2}$, F. Dieken ${ }^{3}$, and B. Loescher ${ }^{3}$ \\ ${ }^{1}$ Ministry of Natural Resources (Canada) \\ ${ }^{2}$ University of Waterloo \\ ${ }^{3}$ Ministry of the Environment (Canada)
}

\begin{abstract}
Mineral-rich springs used by wildlife were studied in order to develop an appropriate sampling technique. The mineral content of the water varied spatially within a lick, apparently because of contamination by nonlick water and animal urine. The spring source usually could be located with a conductivity meter. Samples contaminated by animal urine could be recognized by their high $\mathrm{N}$ content and usually by their color. The distinctive chemical composition of licks is best appreciated by comparing filtered samples of lick water with nonlick water collected nearby. Field filtration was necessary when samples were preserved with acid for trace-metal analysis. Soil samples from lick and nonlick sites revealed of the properties of the spring water, but not as well as water analysis. High levels of $\mathrm{Na}$ were found the spring water of all Ontario licks sampled. Many conflicting results among other studies may be attributable to inappropriate sampling.
\end{abstract}

"It is certainly very strange," wrote Shiras (1912) concerning mineral licks used by wildlife, "that such an interesting subject has never received any serious and comprehensive treatment by sportsmen or scientists."

Since Shiras's observation, despite numerous studies, no comprehensive and satisfactory explanation has been given for the use of mineral licks by North American ungulates. Several workers have found or inferred that mineral licks attract wild ungulates because of abundant $\mathrm{Na}$ (Stockstad et al. 1953, Knight and Mudge 1967, Hebert and Cowan 1971, Weeks and Kirkpatrick 1976). However, there have been many conflicting findings. Dixon (1939), Wright (1956), and Bouchard (1970) found abundant $\mathrm{Na}$ in only some of the licks they studied. Chapman (1939) found natural licks that were rich in $\mathrm{Ca}$ and $\mathrm{Mg}$, but apparently not in $\mathrm{Na}$; and Botkin et al. (1973) appeared to question whether $\mathrm{Na}$ in licks on Isle Royale is of sufficiently high concentration to attract moose (Alces alces). Such disagreement has led to the suggestion that the critical constituents of licks may be trace elements (Cowan and Brink 1949) or sulphur (Hanson and Jones 1976). Shiras's (1912) opinion was that "salt, soda, iron and sulphur, in the order 
given, either singly or in combination" cover the attractive qualities of the hundreds of licks he studied across North America.

In a preliminary study of lick water in Ontario, most samples had high levels of $\mathrm{Na}$; some had high levels of $\mathrm{Ca}$ and other major cations; and some differed from nearby stream water only in trace elements, especially Fe and Mn (Chamberlin et al. 1977). In hindsight, however, we recognized that the methods of collecting and treating these samples could have influenced the results greatly. We therefore wanted to evaluate the effects of sampling technique on lick water chemistry.

Three observations on the behavior of moose and white-tailed deer (Odocoileus virginianus) at licks in Ontario, from a study to be reported in detail elsewhere, helped to point the way. First, it was found that both moose and deer drink copious amounts of water in the licks, but only occasionally consume mud or vegetation in the area. Second, almost all drinking occurred at the specific points where spring water was known or believed to seep into the lick; and experienced animals generally walked directly to these points when entering a lick. Therefore, much of the water that collected in the lick area was largely ignored. Third, moose and deer urinated frequently when using the licks. The urine often was deposited within the lick area of disturbed mud and standing pools, although rarely at the actual spring source.

In view of these findings, we felt that (1) water samples from licks should be collected from the spring source; (2) contamination by animal urine must be avoided; and (3) "control" samples from a nearby stream or lake should be collected. Because lick water is often muddy, we experimented with filtration in the field as a means of making lick and control samples comparable. Finally, because soil samples often are used in studies of licks, we compared soil and water samples at spring-based licks.

We are grateful for assistance in the field by J. McNicol, R. Gollat, H. Hristienko, B. Snider, L. Trodd, L. Walters, and A. Hurly; to L. Spence for analysis of the soil samples; to M. James for bibliographic assistance; to E. Appleyard for valuable discussion; to D. Baggley for assistance with the manuscript; and to $\mathrm{D}$. Roseborough and C. Macinnes for support of the program.

\section{METHODS}

\section{Study Area}

Most of the known wildlife mineral licks in Ontario lie near Lake Nipigon and the north shore of Lake Superior. Eighteen licks in this area have been identified and studied. Seven (Fig. 1) were chosen for the present study because they were thought to be representative of the various physiographic and geological features of licks in the area. Outcropping rock consists of Sibley Group sediments near the Marie Louise lick, diabase and Sibley sediments near the McIntyre Bay and Split Rapids Dam licks, and Osler Group rock near the Finch Head, Gull Colony, and Wilson licks (Ontario Division of Mines 1973). Use of licks by moose and white-tailed deer apparently is proportional to local abundance of the 2 species.

Physical characteristics of some of the licks were described by Chamberlin et al. (1977). Briefly, all licks studied consist of about $200-700 \mathrm{~m}^{2}$ of mud riddled with animal tracks and small pools of standing water. Most of the licks are in low-lying areas, usually with a stream or lake nearby, or with a small stream running through the site. Generally several well-developed animal trails lead to the licks. All licks used in this study, and others in Ontario that have been examined in depth, appear to be fed by springs. However, many of the springs have slow seepage rates so that they can only be discerned with great difficulty, if at all. Because the soil in the licks generally is saturated with water, especially in wet weather, the mud can hold surface water and animal urine in small pools for a week or more. 
Fig. 1. Locations of mineral licks referred to in the text: 1-Mclntyre Bay, 2-Split Rapids Dam, 3-Marie Louise, 4-Finch Head, 5-Gull Colony, 6-Wilson North, 7-Wilson South.

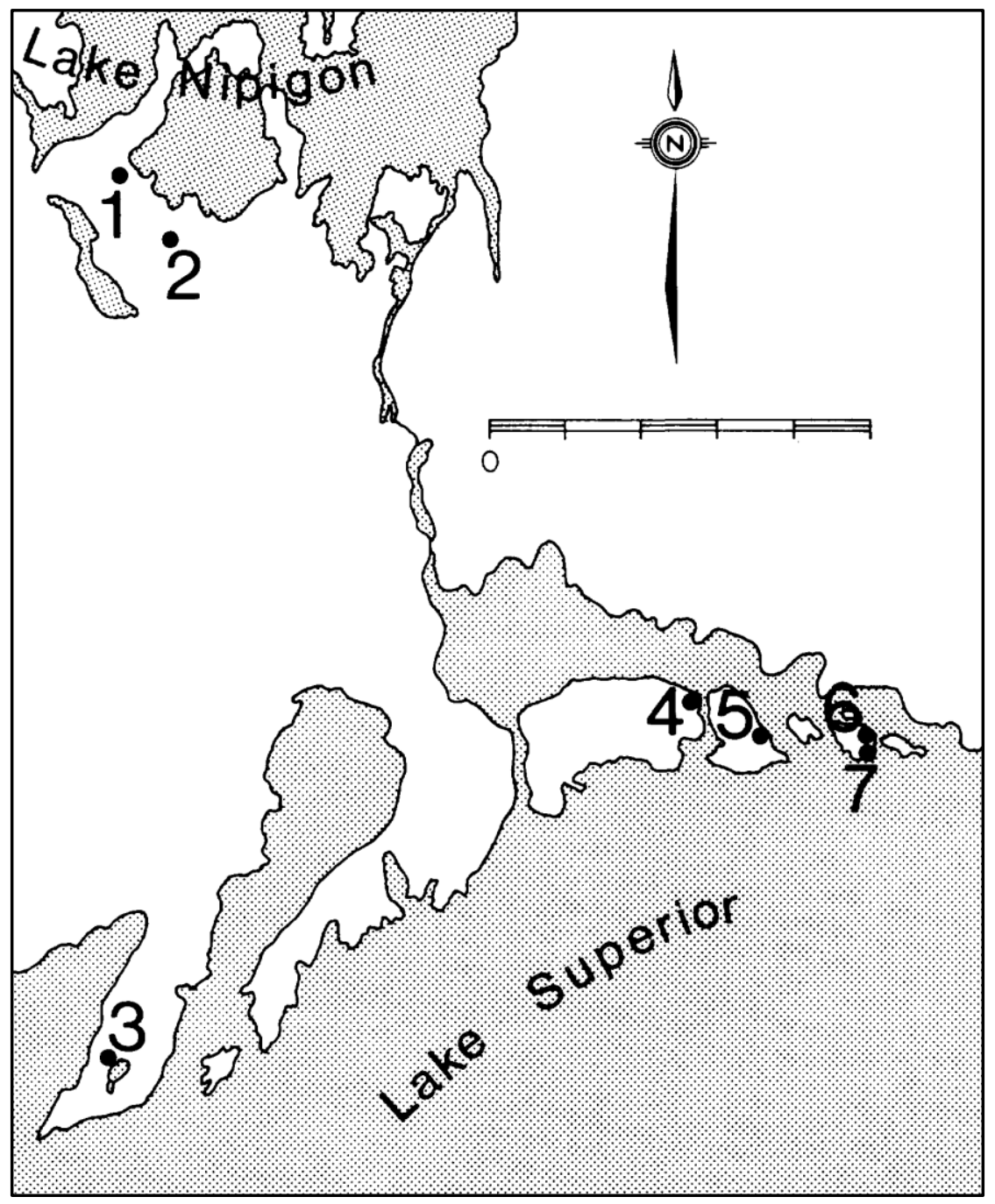

\section{Field Sampling Techniques}

Preliminary work at 4 licks showed that duplicate samples collected from the same spring on the same day had nearly identical levels of the major ions, whereas minor elements ( $N, P$, and trace metals) showed larger differences that seemed related to the muddiness of the sample. Repeated sampling of 3 licks between 1977 and 1979 showed that the spring water remained consistent in levels of major elements throughout the warm season and from year to year. Standing pools of spring water generally became more concentrated in hot weather, presumably because of evaporation, but these differences were very small compared to the differences between lick and nonlick water. From these findings we concluded that a single sampling would characterize the unusual properties of lick water for the major elements, and that filtration would be necessary for analysis of minor components.

Each of the 7 licks was visited once during July or August 1978. An outline map of each lick was drawn showing the areas of disturbed mud and pools of water. A YSI conductivity meter with platinum probe 
then was used to determine the electrical conductance of the water at many locations in the lick, usually 1-3 m apart, wherever there was enough water for a determination. This generally indicated 1 or more points where the conductivity of the water was particularly high. Such places were examined closely, and any spring source was noted by looking for tiny areas where soil particles were moving, or where the water, once disturbed, became clear quickly. If there was an adequate pool of water at the point of highest conductance, water samples were collected from it; if not, a pool was scooped out by hand and the water was allowed to clear before samples were collected.

Filtered samples were taken using an apparatus modified from Kennedy et al. (1976). A filter membrane of $142-\mathrm{mm}$ diameter and $0.45-\mu, \mathrm{m}$ pore size was held in an in-line Plexiglas filter holder. Water was pumped from the lick, through the filter, and directly into the sample bottle using a peristaltic pump and plastic tubing. In this way the water was not aerated or subjected to a vacuum during filtration. The pump head was mounted on a small piece of plywood, and was driven manually with the aid of a brace and bit.

One water sample was collected from each lick. It consisted of 2 liters of filtered water: 1 liter in an acidwashed Nalgene bottle for trace metal analysis, preserved by adding $2 \mathrm{ml}$ of concentrated nitric acid within 24 hours of collection, and 1 liter in a glass bottle for analysis of other mineral constituents.

Detailed sampling was done at 5 of the licks to study the effect of field filtration of water on chemical analysis. Three samples were collected from a single pool of water in each lick: (1) a sample field-filtered as described above, (2) an unfiltered sample of visually clear water scooped carefully from the lick so as to avoid collecting suspended solid matter as much as possible, and (3) a sample of muddy lick water collected after the sediment had been purposely disturbed. To compare the chemical composition of lick and nonlick surface water, 1 field-filtered water sample was collected from the stream nearest to each of 5 licks. In order to compare soil and water samples, a soil sample of about $1 \mathrm{~kg}$ was collected from each of 5 licks at the same location as the water samples, and a "control" sample of the same type of soil was collected 10-100 $\mathrm{m}$ from the lick. The samples were partially air-dried in the field within 7 days of collection.

Previous observations had shown that some moose and deer urine in standing puddles turns a bright red, wine, or brown color within a few hours of deposition. In order to compare lick water with urinecontaminated water, highly colored fluid was collected from 3 locations in the Marie Louise and Mclntyre Bay licks, and a 4th sample was collected from a pool on the edge of the Marie Louise lick where a bull moose had been seen to urinate about 1 minute before. The licks also were used by porcupines (Erethizon dorsatum) and red squirrels (Tamiasciurus hudsonicus). However, these animals generally licked peripheral rocks and mud where spring water is thought to have evaporated, and they probably deposited little or no urine in the licks.

\section{Chemical Analysis}

All water samples that were not filtered in the field were filtered in the laboratory through a $0.45-\mu m$ filter membrane just before analysis. The samples were analyzed using standard laboratory techniques (Ontario Ministry of the Environment 1975) for all cations known to be required by ruminant animals, the major anions in surface waters, total Kjeldahl nitrogen (TKN), and total phosphorus (TP). The elements $\mathrm{Na}, \mathrm{K}, \mathrm{Ca}$, and $\mathrm{Mg}$ were analyzed by atomic absorption spectroscopy; sulfate by an automated colorimetric method using methylthymol blue; TKN and TP by automated colorimetric techniques using the indophenol blue method and the molybdenum blue method with stannous chloride, respectively. Alkalinity, which is chiefly bicarbonate in these waters, was analyzed by automated titration to $\mathrm{pH} 4.5$, and chloride by an automated colorimetric method using ferric thiocyanate. The elements $\mathrm{Co}, \mathrm{Cu}, \mathrm{Mn}, \mathrm{Zn}, \mathrm{Fe}$, 
and Mo were analyzed by atomic absorption after preconcentration with background correction for $\mathrm{Zn}$ and Co; Se was analyzed by hydride-generation flameless atomic absorption.

Soil samples were thoroughly air-dried in the laboratory, ground, and passed through a 2-mm sieve. Ten grams of soil were then leached with $300 \mathrm{ml} 1 \mathrm{~N}$ ammonium acetate adjusted to $\mathrm{pH} 7.0$, with a percolation rate of 1 drop/second. Analysis was done for the major cations found in the lick water: $\mathrm{Ca}$ and $\mathrm{Mg}$ by atomic absorption, $\mathrm{Na}$ and $\mathrm{K}$ by flame emission spectrophotometry.

\section{RESULTS}

In the Mclntyre Bay lick, the conductivity of the water was particularly high in 1 small area, and decreased irregularly outward over the rest of the lick (Fig. 2). A careful search revealed a small, but visible, jet of water in the area of highest conductivity. A similar pattern was seen in the Marie Louise and Finch Head licks; maximum conductivities at the spring source were 1,220 and $900 \mu$,mhos/cm, respectively.

Fig. 2. Mclntyre Bay lick showing contours of conductivity (in $\mu, \mathrm{mhos} / \mathrm{cm}$ ) of the water, based on 34 measurements in different parts of the lick.

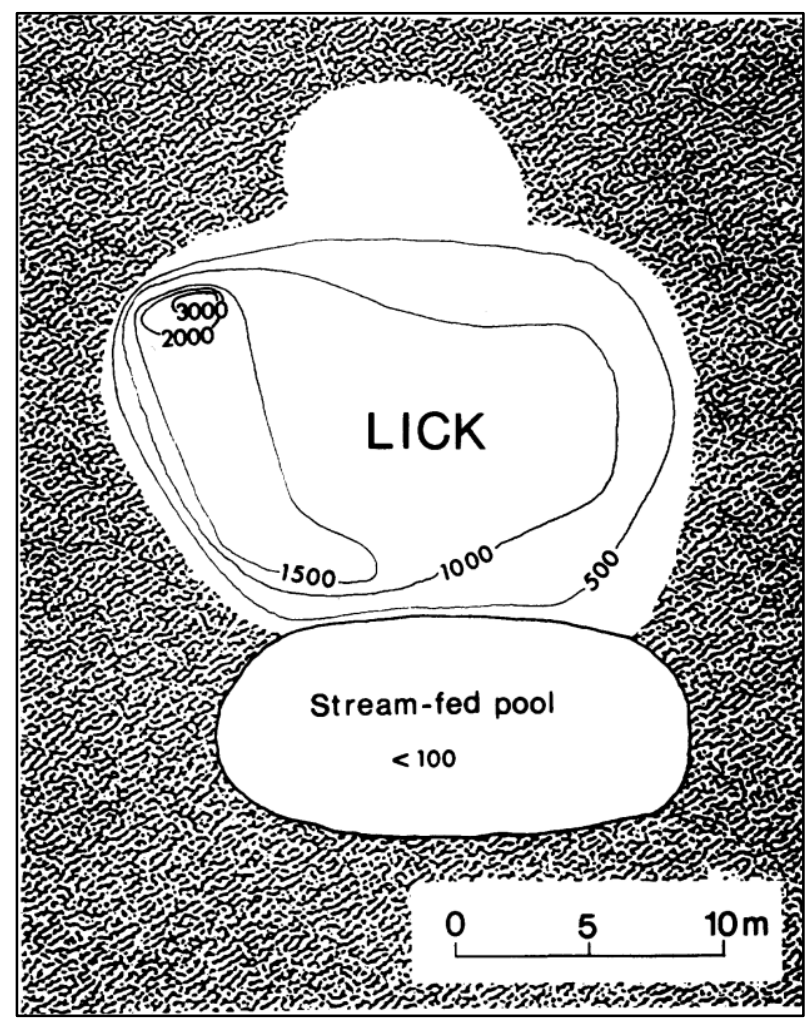

Maximum conductivities at the Wilson and Gull Colony licks were 260 and $320 \mu$,mhos/cm, respectively, and there was no simple pattern of conductivity contours. A spring source was found the Wilson South lick but not at the others.

Table 1 shows the chemical content of water from the Marie Louise lick collected in the 3 ways. Similar levels of the major ions occurred in all 3 samples; TKN was slightly higher in the muddy sample. However, the acidified muddy sample had very high levels of $\mathrm{Fe}, \mathrm{Mn}$, and $\mathrm{Zn}$, with a similar, but less pronounced, trend for $\mathrm{Cu}$ and $\mathrm{Co}$. The clear sample contained more Fe than the field-filtered sample. 
Table 1. Chemical composition (ppm) of water samples from the Marie Louise lick treated in 3 different ways. Analysis was based on unacidified water (above the dividing line) and acidified water (below).

\begin{tabular}{|lccc|}
\hline & & Treatment of sample & \\
\cline { 2 - 4 } & Field-filtered & Visually clear & Muddy \\
\hline $\mathrm{Na}$ & 115 & 114 & 123 \\
$\mathrm{~K}$ & 7.3 & 7.5 & 8.6 \\
$\mathrm{Ca}$ & 86 & 85 & 87 \\
$\mathrm{Mg}$ & 28.0 & 28.0 & 27.5 \\
$\mathrm{SO}_{4}$ & 6.5 & 6.0 & 5.0 \\
$\mathrm{HCO}_{3}$ & 170 & 170 & 173 \\
$\mathrm{Cl}$ & 300 & 295 & 310 \\
$\mathrm{TKN}$ & 0.73 & .087 & 1.68 \\
$\mathrm{TP}$ & & 0.009 & 0.035 \\
& & & \\
$\mathrm{Fe}$ & 0.20 & 0.86 & 26 \\
$\mathrm{Mn}$ & 0.28 & 0.30 & 2.2 \\
$\mathrm{Cu}$ & $<0.01$ & 0.01 & 0.02 \\
$\mathrm{Zn}$ & $<0.01$ & 0.01 & 0.17 \\
$\mathrm{Co}$ & $<0.02$ & $<0.02$ & 0.05 \\
$\mathrm{Mo}$ & $<0.02$ & $<0.02$ & $<0.02$ \\
$\mathrm{Se}$ & $<0.001$ & $<0.001$ & $<0.001$ \\
\hline
\end{tabular}

Table 2. Chemical composition (ppm) of field-filtered water from 5 licks and 5 streams. All lick and control samples were at or below the detection limit for $\mathrm{Cu}(0.01), \mathrm{Zn}(0.01), \mathrm{Co}(0.02)$, Mo (0.02), and Se (0.001).

\begin{tabular}{|c|c|c|c|c|c|c|c|c|c|c|c|}
\hline \multirow[b]{2}{*}{ Location } & \multicolumn{9}{|c|}{ Not acidified } & \multicolumn{2}{|c|}{ Acidified } \\
\hline & $\mathrm{Na}$ & $\mathrm{K}$ & $\mathbf{C a}$ & Mg & $\mathrm{SO}_{4}$ & $\mathrm{HCO}_{3}$ & $\mathrm{Cl}$ & TP & TKN & $\mathrm{Fe}$ & Mn \\
\hline \multicolumn{12}{|l|}{ Lick Sample } \\
\hline McIntyre Bay & 851 & 7.5 & 6 & 2.0 & 18.0 & 203 & 1,230 & 0.475 & 0.71 & 0.28 & 0.02 \\
\hline Split Rapids Dam & 453 & 5.5 & 24 & 8.5 & 36.5 & 113 & 700 & 0.183 & 0.47 & 0.55 & 0.02 \\
\hline Marie Louise & 115 & 7.3 & 86 & 28 & 6.5 & 170 & 300 & 0.220 & 0.73 & 0.20 & 0.04 \\
\hline Wilson South & 43 & 0.5 & 8 & 1.8 & 4.5 & 112 & 1 & 0.069 & 0.24 & 0.10 & 0.04 \\
\hline Gull Colony & 42 & 2.2 & 14 & 1.8 & 2.0 & 110 & 17 & 0.136 & 2.62 & 0.17 & 0.03 \\
\hline \multicolumn{12}{|l|}{ Stream Sample } \\
\hline Mclntyre Bay & 11 & 0.3 & 13 & 2.5 & 4.5 & 44 & 13 & 0.350 & 0.63 & 0.10 & 0.02 \\
\hline Split Rapids Dam & 4 & 0.2 & 10 & 3.0 & 6.5 & 34 & 4 & 0.179 & 0.58 & 0.10 & 0.02 \\
\hline Marie Louise & 4 & 0.8 & 29 & 11 & 10.5 & 107 & 4 & 0.150 & 0.39 & 0.10 & 0.02 \\
\hline Wilson South & 2.2 & 0.2 & 8 & 3.3 & 9.5 & 26 & 1 & 0.063 & 0.36 & 0.24 & 0.02 \\
\hline Gull Colony & 2.9 & 0.3 & 7 & 4.2 & 11.5 & 51 & 1 & 0.127 & 0.39 & 0.38 & 0.02 \\
\hline
\end{tabular}

Results for all licks were similar. For all 3 sampling techniques, levels of the major ions often were within $10 \%$ of each other and they never differed by more than a factor of 4 . The differences could be due to local variation in ion concentrations within the sampling areas. Levels of the trace metals, especially $\mathrm{Fe}$ and $\mathrm{Mn}$, were higher in muddy samples than in field-filtered samples, often by a factor of 10,100 , or even 1,000 . 
The chemical composition of field-filtered water from the 5 licks and 5 nearby streams is shown in Table 2. Among the lick samples there was considerable variation; $\mathrm{Na}$, for example, varied from 42 to $851 \mathrm{ppm}$. However, each lick sample differed in $\mathrm{Na}$ content from its nearby stream water sample by at least an order of magnitude. For $\mathrm{K}$, the range in values of lick samples overlapped the range for nonlick samples, although there were consistent differences between each lick and its respective comparison site. Regional differences were apparent; for example, high levels of $\mathrm{Na}$ were accompanied by high $\mathrm{Cl}$ in the 3 licks in the Lake Nipigon and Sibley areas, but by high $\mathrm{HCO}_{3}$ in the Wilson South lick.

The 4 samples believed to be contaminated by urine (Table 3) contained less $\mathrm{Na}$ and $\mathrm{Cl}$; more TKN, K, $\mathrm{SO}_{4}$, and alkalinity (presumably because of the presence of dissociated organic acids); and generally more $\mathrm{Ca}$ and $\mathrm{Mg}$ than corresponding lick samples (Table 2).

The soil samples from the lick and nonlick locations contained more $\mathrm{Ca}$ than $\mathrm{Na}$ in every case (Table 4). Levels of Na varied considerably, but were consistently higher in lick than nonlick samples.

Table 3. Chemical composition (ppm) of urine-contaminated water collected at lick sites. Samples were filtered in the laboratory before analysis. Phosphorus is not reported because of interference in the test.

\begin{tabular}{|lcccccccc|}
\hline Lick Location & $\mathbf{N a}$ & $\mathbf{K}$ & $\mathbf{C a}$ & $\mathbf{M g}$ & $\mathbf{S O}_{\mathbf{4}}$ & $\mathbf{H C O}_{3}$ & $\mathbf{C l}$ & $\mathbf{T K N}$ \\
\hline Marie Louise & 35 & 20 & 102 & 55 & 35 & 1,720 & 130 & 3,400 \\
Marie Louise & 11 & 143 & 82 & 19 & 26 & 1,050 & 34 & 280 \\
Marie Louise & 24 & 137 & 108 & 44 & 66 & 1,070 & 63 & 260 \\
McIntyre Bay & 123 & 89 & 91 & 35 & 58 & 880 & 150 & 265 \\
\hline
\end{tabular}

\section{DISCUSSION}

All licks reported in this paper were characterized by high levels of $\mathrm{Na}$ in the water. Similar findings by Dalke et al. (1965), Knight and Mudge (1967), Hebert and Cowan (1971), Weeks and Kirkpatrick (1976), and Weeks (1978) suggest that $\mathrm{Na}$ is probably the main element sought in the various areas. In addition, moose and white-tailed deer are attracted to Na-rich pools that accumulate as a result of winter salting of roads (Fraser 1979), and in a choice experiment they selectively consumed $\mathrm{Na}$ compounds (Fraser and Reardon 1980). Finally, the limited evidence from urine-contaminated lick samples suggests that the animals are selectively retaining $\mathrm{Na}$ and $\mathrm{Cl}$ (comparison of Tables 2 and 3). Other studies (Cowan and Brink 1949, Peterson 1953, Wright 1956, Bouchard 1970, Botkin et al. 1973, Chamberlin et al. 1977) either do not support $\mathrm{Na}$ being the sole chemical constituent sought by moose in licks, or present evidence against it. However, in light of the care that must be taken to obtain uncontaminated lick water, that evidence appears less convincing.

Locating a suitable point for sampling is an important 1st step in any analysis scheme. Lick water at the Mclntyre Bay, Split Rapids Dam, Marie Louise, and Finch Head licks was of much higher conductivity than other surface water nearby. The conductivity appeared to be highest at the spring source and to decline with increasing distance, presumably as the spring water became diluted with surface drainage. Conductivity measurements could therefore be used to locate a suitable sampling point at the spring source. In the Gull Colony and Wilson licks, conductivity was less helpful in locating a spring source because there was a smaller difference in conductivity between the lick and nonlick water.

In a Quebec study, Bouchard (1970) found 3 licks with conspicuous springs. Water from these licks had high conductivity and $\mathrm{Na}$ levels. Most of the other licks studied lacked a conspicuous source, and the samples collected at these sites resembled samples of stream water in conductivity and in levels of $\mathrm{Na}$ and other major ions. Failure to find and sample the source of the water also may explain why Peterson 
(1953), Wright (1956), and Chamberlin et al. (1977) found low levels of electrolytes in some of their lick samples. Botkin et al. (1973) reported a mean Na concentration of only $24 \mathrm{ppm}$ in 9 samples of lick water from Isle Royale. However, the large standard deviation (17.7) shows that some samples were much richer in $\mathrm{Na}$. The low mean value may result from averaging richer samples near the spring source with other samples diluted with nonlick water.

Table 4. Chemical composition (in meq/100 $\mathrm{g}$ of air-dried material) of soil samples from licks and comparison locations.

\begin{tabular}{|c|c|c|c|c|c|c|c|c|}
\hline \multirow[b]{2}{*}{ Location } & \multicolumn{2}{|c|}{$\mathrm{Na}$} & \multicolumn{2}{|c|}{ K } & \multicolumn{2}{|c|}{$\mathrm{Ca}$} & \multicolumn{2}{|c|}{ Mg } \\
\hline & Lick & Comp. & Lick & Comp. & Lick & Comp. & Lick & Comp. \\
\hline Mclntyre Bay & 3.28 & 0.09 & 0.10 & 0.21 & 22.3 & 14.8 & 1.07 & 3.54 \\
\hline Split Rapids Dam & 3.35 & 0.22 & 0.11 & 0.24 & 8.5 & 21.1 & 1.07 & 4.11 \\
\hline Marie Louise & 0.49 & 0.07 & 0.39 & 0.67 & 19.5 & 12.4 & 3.37 & 2.71 \\
\hline Wilson South & 0.50 & 0.06 & 0.52 & 0.63 & 18.2 & 21.9 & 4.61 & 8.13 \\
\hline Wilson North & 2.02 & 0.14 & 0.20 & 0.14 & 18.9 & 32.0 & 3.78 & 13.24 \\
\hline
\end{tabular}

Because Na levels of 20-50 ppm, seen in some licks, are not uncommon in groundwater in many parts of the continent (Hem 1970), the unusual nature of such levels in licks can be demonstrated only by comparison with nearby stream or lake water that also is available to the animals using the licks. A lack of comparison samples in several previous studies makes the various levels of $\mathrm{Na}$ and other elements difficult to interpret (Cowan and Brink 1949, Peterson 1953, Wright 1956, Dalke et al. 1965).

Because lick water is often rather turbid, while nearby streams or lakes are likely to be clearer, water samples from the 2 sources should be filtered in the same manner before their chemical compositions are compared. In our study, samples filtered in the laboratory were similar to samples filtered in the field in major cations and anions analyzed from unacidified water. However, the concentrations of trace metals were generally higher if the samples were not filtered before being preserved by acidification. The acidification probably caused partial dissolution or release of trace metals that were present as colloidal particles in suspension and as coatings on soil particles. In previous studies in which the water samples were not filtered, some high levels of iron and other trace metals in lick samples may reflect solid matter in the water (Peterson 1953, Bouchard 1970, Chamberlin et al. 1977).

Lick samples collected without adequate care could be contaminated easily by animal urine. This would lead to erroneous results. We found the urine-contaminated samples to be different from the spring water samples in chemical composition. However, all the contaminated samples and none of the spring samples had very high levels of TKN after filtration. Analysis for TKN should provide an easy method of checking samples for contamination by ungulate urine.

Numerous studies have used analysis of soil or rock samples to characterize the unusual properties of spring-fed licks. This type of indirect approach should be discouraged, however, because chemistries derived from soil or rock analysis are a complex function of the dissolution technique, the mineralogic composition of the sample, and the exchange capacity and selectivity coefficients governing ion exchange between the solid and the solution. In our study, soil samples collected at the spring source did have higher $\mathrm{Na}$ levels than similar soil collected outside the lick. However, the differences were not as great as those revealed by the water samples, and the high levels of $\mathrm{Na}$ can be explained partly by $\mathrm{Na}$ in lick water contained in the soil before the samples were air dried. In addition, the soil samples consistently had more $\mathrm{Ca}$ than $\mathrm{Na}$, probably because of a source of lime in the soil itself. 
Difficulties in the use of soil or rock samples were evident in earlier studies. Dalke et al. (1965) concluded that Narich water was attracting elk (Cervus canadensis) to natural licks in Idaho, but the results of lick soil analysis were extremely variable and did not show high Na levels in all samples. Similarly, Knight and Mudge (1967) found high Na levels in water samples from lick springs, but only "erratic differences" when rock samples were compared. In other studies that have found high levels of $\mathrm{Na}$ in spring water, analysis of nearby soil has not revealed commensurate levels (Wright 1956, Bouchard 1970).

\section{LITERATURE CITED}

BOTKIN, D. B., P. A. JORDAN, A. D. DOMINSKI, H. S. LOWENDORF, AND G. E. HUTCHINSON. 1973. Sodium dynamics in a northern ecosystem. Proc. Natl. Acad. Sci. U.S.A. 70:2745-2748.

BOUCHARD, R. 1970. Etude chimique preliminaire des vasieres de la reserve Matane, 1965. Serv. Faune Que. Rapp. 5:343-352.

CHAMBERLIN, L. C., H. R. TIMMERMANN, B. SNIDER, F. DIEKEN, B. LOESCHER, AND D. FRASER. 1977. Physical and chemical characteristics of some natural licks used by big game animals in northern Ontario. Trans. North Am. Moose Conf. Workshop 13: 200-214.

CHAPMAN, F. D. 1939. The whitetail deer and its management in southeastern Ohio. Trans. North Am. Wildl. Conf. 4: 257-267.

COWAN, I. McT., AND V. C. BRINK. 1949. Natural game licks in the Rocky Mountain National Parks of Canada. J. Mammal. 30: 379-387.

DALKE, P. D., R. D. BEEMAN, F. J. KINDEL, R. J. ROBEL, AND T. R. WILLIAMS. 1965. Use of salt by elk in Idaho. J. Wildl. Manage. 29:319-332.

DIXON, J. S. 1939. Some biochemical aspects of deer licks. J. Mammal. 20: 109.

FRASER, D. 1979. Sightings of moose, deer, and bears on roads in northern Ontario. Wildl. Soc. Bull. 7: 181-184.

----, AND E. REARDON. 1980. Attraction of wild ungulates to mineral-rich springs in central Canada. Holarctic Ecol. 3: 36-40.

HANSON, H. C., AND R. L. JONES. 1976. The biochemistry of blue, snow and Ross' geese. III. Nat. Hist. Surv. Spec. Publ. 1. 281pp.

HEBERT, D., AND I. McT. COWAN. 1971. Natural salt licks as a part of the ecology of the mountain goat. Can. J. Zool. 49: 605-610.

HEM, J. D. 1970. Study and interpretation of the chemical characteristics of natural waters. U.S. Geol. Surv. Water Supply Pap. 1473. 363pp.

KENNEDY, V. C., E. A. JENNE, AND J. M. BURCHARD. 1976. Backflushing filters for field processing of water samples prior to trace-element analyses. U.S. Geol. Surv. Open-File Rep. 76-126. 12pp.

KNIGHT, R. R., AND M. R. MUDGE. 1967. Characteristics of some natural licks in the Sun River area, Montana. J. Wildl. Manage. 31 : 293-299.

ONTARIO DIVISION OF MINES. 1973. Nipigon-Schreiber. Ont. Div. Mines Geol. Compil. Ser. Map 2232. 
ONTARIO MINISTRY OF THE ENVIRONMENT. 1975. Outline of analytical methods. Ontario Ministry of the Environment, Toronto. 94pp.

PETERSON, R. L. 1953. Studies of the food habits and the habitat of moose in Ontario. Contrib. R. Ont. Mus. Zool. Palaeontol. 36. 49pp.

SHIRAS, G. 1912. The white sheep, giant moose, and smaller game of the Kenai Peninsula, Alaska. Natl. Geogr. Mag. 23:423-494.

STOCKSTAD, D. S., M. S. MORRIS, AND E. C. LORY. 1953. Chemical characteristics of natural licks used by big game animals in western Montana. Trans. North Am. Wildl. Conf. 18:247-258.

WEEKS, H. P. 1978. Characteristics of mineral licks and behavior of visiting white-tailed deer in southern Indiana. Am. Midi. Nat. $100: 384-395$.

----, AND C. M. KIRKPATRICK. 1976. Adaptations of white-tailed deer to naturally occurring sodium deficiencies. J. Wildl. Manage. 40:610-625.

WRIGHT, B. S. 1956. The moose of New Brunswick. A report to the Minister of Lands and Mines, New Brunswick. Northeastern Wildlife Station, Fredericton, N.B. 63pp. 